\title{
DOES FINANCIAL INTEGRATION SPUR ECONOMIC GROWTH? \\ NEW EVIDENCE FROM THE FIRST ERA OF FINANCIAL GLOBALIZATION
}

\author{
MORITZ SCHULARICK \\ THOMAS M. STEGER
}

CESIFO WORKING PAPER NO. 1691

CATEgORY 5: Fiscal POLICY, MaCroeCONOMICS AND GROWTH MARCH 2006

\footnotetext{
An electronic version of the paper may be downloaded

- from the SSRN website:

www.SSRN.com

- from the CESifo website: www.CESifo-group.de
} 


\title{
DOES FINANCIAL INTEGRATION SPUR ECONOMIC GROWTH? NEW EVIDENCE FROM THE FIRST ERA OF FINANCIAL GLOBALIZATION
}

\begin{abstract}
Does international financial integration boost economic growth? The question has been discussed controversially for a long time. As of yet, robust evidence for a positive impact is lacking (Edison et al., 2002). However, there is substantial narrative evidence from economic history that highlights the contribution European capital made to economic growth of peripheral economies before 1914. We have compiled the first comprehensive data set to test this hypothesis. The main finding is that there was indeed a significant and robust growth effect. Our theoretical explanation stresses property rights protection as a prerequisite for the standard neoclassical model to work properly.
\end{abstract}

JEL Code: F15, F21, F30, N10, N20, O11, O16.

Keywords: international financial integration, economic growth, first era of globalization.

\author{
Moritz Schularick \\ Free University of Berlin \\ Pestalozzistr. 56 \\ 10627 Berlin \\ Germany \\ moritz.schularick@amiyacapital.com
}

\author{
Thomas M. Steger \\ Institute of Economic Research \\ ETH Zurich \\ Zürichbergstr. 18 \\ 8032 Zurich \\ Switzerland \\ tsteger@ethz.ch
}

This version: March 2006

We would like to thank Michael Clemens, Niall Ferguson, André Hofmann, Angus Maddison, Christopher M. Meissner, Maurice Obstfeld, Sevket Pamuk, Alan M. Taylor, Marc Weidenmier and Jeffrey Williamson for generously sharing their data. Thorsten Beck, Hali Edison, Henrik Enderlein, Carl-Ludwig Holtfrerich, David Leblang, Ross Levine, David Roodman, and Torsten Slok provided helpful comments. We thank Lilli Bialluch for research assistance. 


\section{Introduction}

The nexus between international financial integration - the degree to which an economy is integrated with and open to the international capital market - and economic growth continues to be one of the most debated issues among international economists. Do financially more open economies grow faster than closed ones, precisely because of their openness to the global capital market? Are policies sensible that promote growing international financial integration, hence financial globalization? In this paper, we aim to shed a new light on these questions by looking at the evidence from the first era of financial globalization from 18801913.

In a perfect neoclassical textbook world, there are good arguments for a positive growth impact of integration with the international capital market, especially for developing countries. By tapping the pool of global savings capital-poor countries could free themselves of a binding constraint on economic growth - lack of capital. Closer financial integration could also strengthen domestic financial systems leading to more investment, more efficient allocation of capital and higher growth (Levine, 2001). On a global level, the efficient allocation of capital and international risk sharing would be promoted (Obstfeld, 1994). However, arguments against the economic wisdom of openness to global capital flows have also been put forward. Financial integration does not have to be welfare enhancing in the presence of other distortions such as trade barriers and weak institutions, or if information asymmetries affect the proper working of the international financial market (Bhagwati 1998; Stiglitz, 2000).

Despite a rich body of contributions, the empirical literature is still inconclusive with regard to the financial integration-growth nexus. Empirical work by Grilli and Milesi-Ferretti (1995), Kraay (1998), Edison et al. (2002) and Fratzscher and Bussière (2004) has not confirmed a robust long-term impact of financial openness on growth. Their results have mirrored the early and well-known study by Rodrik (1998, p. 9) who concluded that "capital controls are essentially uncorrelated with long-term economic performance". On the other side of the spectrum are studies that find support for a relationship between openness to the global capital market and economic growth such as Quinn (1997), Bekaert (2001), and Edwards (2001). More recent research has aimed to throw more light on the question whether the positive growth impact of financial integration depends on third factors such as a sound institutional framework, but the results remained mixed at best (Edison et al., 2002; Klein, 2005). Detailed reviews of the literature on financial openness and growth have been given by Eichengreen (2002) and Edison et al. (2004), we thus content ourselves with this brief review. A balanced summary of empirical research on the issue has been given in a study by the research department of the International Monetary Fund (IMF), one of the main proponents of capital account liberalization in the 1990s:

\section{Theoretical models have identified a number of channels through which international financial integration can promote economic growth in developing countries... However, there is as yet no clear and robust empirical proof that the effect is quantitatively significant. (Prasad et al., 2003, p.1)}

One reason why empirical research on the financial integration-growth link remained inconclusive to date is that different approaches and econometric techniques made it difficult to synthesize the results. Although the majority of papers took similar (albeit not identical) cross-country growth models as their starting point, marked differences remained with regard to the sample of countries, the period under investigation and the estimation techniques 
employed. ${ }^{1}$ Not least, the measurement of the key variable, namely the degree of financial openness, was controversial. While some authors looked at the presence or absence of legal restrictions on financial transactions, others have opted to measure financial integration via the actual extent of capital flows.

It is for the sake of comparability that we are intentionally conservative throughout this paper with regard to changing the underlying growth model, introducing new estimation techniques or a new measure for financial integration. On the contrary, we intentionally rely on models and techniques employed before and aim to ensure comparability of our results with previous studies. This is because the most important innovation of this paper is in a different field: we aim to benchmark the present to the past. Economic historians have often underscored the contribution that international capital flows made to economic growth in developing countries during the "first era of globalization" - the years of the classical gold standard from 1870-1914. Yet it has never been tested econometrically for a broad crosssection of countries whether the first era of financial globalization does indeed provide evidence that financial integration can spur growth.

The main question this paper tackles reads as follows: Has international financial openness promoted growth in the first era of global finance? We have put considerable effort into assembling the largest possible dataset for the years 1880-1914. It covers 24 developing and developed countries. We use capital inflows from the UK (in relation to GDP) as a proxy for the degree of financial integration of individual countries. These detailed capital flow data are available from a recently published analysis of the geographical patterns of stock and bond issues at the London Stock Exchange (Stone, 1999).

The new dataset allows us to show that - in stark contrast to the ambiguous findings in contemporary research - international financial integration had a statistically significant effect on growth in the first era of global finance. In addition, we can exclude that this finding is purely driven by different estimation techniques or model specification, because we first run our regressions on a contemporary dataset with the aim of reproducing the results of - what we consider - the most comprehensive contemporary study (Edison et al., 2002). In a second step we run the identical model with the same econometric methodology on our newly collected historical dataset. It is thus the data, not different model specifications or econometric techniques, that lead us to conclude that the first era of financial globalization proves a positive relationship between international financial integration and economic growth.

Our core findings support all these economists who believe in the virtues of international capital mobility - and, incidentally, the profession of economic historians who have for a long time pointed to the important role of foreign capital for growth in the periphery before WW1. In other words, the late $19^{\text {th }}$ and early $20^{\text {th }}$ centuries' experience demonstrates that international financial integration can contribute to higher growth. This opens up a potentially fruitful roadmap for future research which we briefly discuss in the last part of the paper: Why did financial openness promote growth back then but no longer today?

Our study is related to two strands in recent research in international economics. First, we are methodologically indebted to the rich contemporary literature that pioneered empirical investigation of the financial integration-growth nexus. In particular, we rely on the work of Edison et al. (2002). Our study also relates to Eichengreen and Leblang (2003) who analyzed the relationship between financial openness and growth over the entire $20^{\text {th }}$ century. Yet while Eichengreen and Leblang focus on the long-run effects of financial openness over different international policy regimes, we contrast two periods of high international financial

\footnotetext{
${ }^{1}$ See the discussion in Edison et al. (2002).
} 
integration. Second, we take inspiration from recent research on "globalization in historical perspective" (Bordo et al., 2003; Obstfeld and Taylor, 2004; Ferguson and Schularick, 2005), a recent strand of research whose main idea is to explore the first episode of high international capital mobility with an eye on policy lessons for today.

The structure of this paper is as follows. In the following section, we briefly present the empirical strategy and introduce our new dataset. The third and fourth part present and discuss the empirical results for the contemporary and historical periods. In the fifth section we present a preliminary explanation for the diverse impact of capital market integration in historical and modern times. The last section summarizes the main findings and concludes.

\section{Empirical Strategy, Conceptual Issues and Data}

The overall empirical strategy of this paper runs as follows: We use a newly collected historical dataset to test whether there is empirical evidence that financial integration translated into higher growth in the first era of financial globalization. To arrive at fully comparable results with contemporary studies on the financial integration-growth nexus, we use the same models and econometric techniques as the recent literature. We run identical growth regressions both on a contemporary (1980-2002) and a newly assembled dataset for the first era of financial globalization (1880-1913). We also align our empirical analysis to the most comprehensive contemporary study (Edison et al., 2002). In addition, we test the sensitivity of our results across two different growth models found in the recent literature.

There is substantial narrative evidence from economic history that highlights the contribution European capital made to economic growth of peripheral economies before 1914 (Feis, 1965; Woodruff, 1966). The degree of international financial integration reached before 1914 was truly impressive. In the decades before WW1, gross foreign investments in relation to gross domestic product (GDP) in 1913 stood at about 200 percent in Argentina, Chile and South Africa, and at or above 100 percent in countries such as Brazil, Mexico, Egypt, and Malaysia - actually about twice as high as the corresponding figures at the end of the 1990s (Twomey, 2000). Not only North and South America were well integrated into the international capital market. Southern and Eastern Europe, Africa and Asia all attracted considerable amounts of capital (Stone, 1999). European investors financed American railroads, Argentinean farms, sewerage systems in the Middle East, ports in Asia and telegraph networks in Africa. From the historical narrative, it would appear that integration into the global capital market could have been an important growth driver. But does this narrative stand up to detailed econometric investigation of a broad cross-country sample?

Contemporary research on the growth effects of international financial integration has typically regressed the growth rate of real per capita GDP growth on a measure for the degree of international financial integration plus a vector of control variables which proxy fundamental growth drivers such as human capital and initial GDP per capita as a neoclassical convergence term. However, the models employed in previous studies differed in two important respects: On the one hand with regard to the measures for the degree of financial integration, on the other with regard to the vector of control variables. Both issues need to be addressed briefly.

Financial integration - or financial openness as it has also been called in analogy to openness to trade in goods - has on the one hand been measured by the extent to which legal barriers impede the free flow of capital (Quinn, 1997; Rodrik, 1998). On the other hand, along the lines of the empirical literature on trade openness and growth - in which trade openness is typically measured by the value of traded goods and services over GDP - one can argue that financial openness should be measured quantitatively. Kraay (1998) and Edison et al. (2004) 
have looked at various measures of gross capital flows and stocks over GDP as quantitative indicators for the degree of international financial integration.

Eichengreen (2001) and Edison et al. (2004) discuss the advantages of both approaches. Clearly, the choice of the indicator is not only a question of convenience and data availability. For example, a country may operate capital controls, but they could be leaky or selective so that despite formal legal barriers, the actual degree of international financial integration could be quite substantial. Using a quantitative measure for the degree of integration would in this case seem to improve greatly as it would show a high degree of openness to international capital. However, in their comprehensive study Edison et al. (2002) test virtually all available indicators, rule-based as well as quantitative, but find no robust evidence for a positive growth effect of either one for the period 1980 to 2000 .

In this study we use a measure that was tested (without clear results for the 1980-2000 period) by Edison et al. (2002) - gross inflows of direct foreign investment and portfolio flows over GDP. It would seem that this indicator is very likely to capture the potential growth effects of capital inflows. But our choice is also data-driven. For the first period of globalization gross inflows of capital are the only variable for which we possess reliable data, and formal capital controls were unheard of in this period.

The second main issue in which contemporary studies have differed relates to the specification of the empirical model. Some authors have argued that short-term policy variables like the budget deficit and the inflation rate need to be included (Edison et al., 2002). Others have opted to control for a smaller set of long-run determinants of economic growth mirroring the results of Barro and Sala-I-Martin (1992) and the robustness analyses by Levine and Renelt (1992). ${ }^{2}$ In particular, the inclusion of the investment ratio has proved problematic. ${ }^{3}$ Klein and Olivei (2001), Edison et al. (2002), McLean and Shrestsha (2002), Eichengreen and Leblang (2003), Obstfeld and Taylor (2003), Bekaert et al. (2004) did not include it, on grounds of potential endogeneity. Other authors such as Rodrik (1998), Arteta et al. (2001), Edwards (2001) and Klein (2005) explicitly control for different investment ratios at the beginning of the observation period. We follow an intermediate strategy and employ three different empirical models. The first excludes the investment ratio, whereas the second and the third include it, controlling for its potential endogeneity. Since the investment ratio is one of the most important explanatory determinants of long-run growth, we hold that it should be included, at least in some specifications, to test the sensitivity of the results.

To make our findings independent from potentially parsimonious specifications, we specify three different models: Model (I) is an exact reproduction of the benchmark regression of Edison et al. (2002), i.e. we regress real per capita growth on initial income, average years of schooling (proxying human capital), average consumer price inflation and budget deficits, plus the period average of capital inflows to GDP as a measure of international financial integration. Model (II) is identical to (I), but adds the investment ratio. Model (III) drops the two policy variables (inflation and budget deficit) from (II), but adds population growth. It thus relates most closely to the fundamental growth regressions of Barro and Sala-I-Martin

\footnotetext{
${ }^{2}$ It can be argued that additional policy variables are appropriate if international financial integration is measured on a quantitative ("de facto") basis as the policy performance is likely to be a central factor determining the attractiveness of a country to foreign investors.

${ }^{3}$ There is both an endogeneity and a collinearity problem. Economic theory suggests that growth should depend on the average investment ratio of the period under study. On the other hand, it is plausible to argue that the investment ratio depends on expected growth. Hence, the investment ratio must be considered as being potentially endogenous with respect to the growth rate. As a consequence, some authors have used the initial investment ratio directly or used it to instrument the average investment ratio. Moreover, it is plausible to think that international financial integration mainly affects economic growth by boosting investments. In this case, international financial integration and the investment ratio should be highly correlated.
} 
(1992) and the robustness analysis by Levine and Renelt (1992). Recall that we run all three models on contemporary and historical data.

We also follow the literature in carrying out the empirical analysis via two different econometric approaches. First, starting at the lower end of econometric sophistication, we run a simple cross-sectional regression on the periods under investigation. This is to say, we use only one observation per country. Second, we move to the higher end of econometric techniques by running a generalized methods of moment (GMM) dynamic panel estimation. ${ }^{4}$ This two-step approach allows to combine the advantages of both estimators (Edison et al., 2004; Eichengreen and Leblang, 2003; Fratzscher and Bussière, 2004). While the results of the cross-section are easy to interpret and communicate, this relatively simple method could bias the findings due to the omission of country fixed effects, a low number of observations, and possible endogeneity of explanatory variables. It should be noted that, in the underlying context, the dynamic panel estimation is particularly helpful because it enables us to explicitly address the potential endogeneity of the capital flow variable. This is important because an economy that exhibits high growth will likely become much more attractive for foreign investors.

The cross-sectional regression, which is estimated with heteroskedasticity robust standard errors, takes the following form:

$$
\Delta y_{i}=\alpha+\beta I F I_{i}+\gamma^{\prime} \mathbf{X}_{i}+\varepsilon_{i},
$$

where $\Delta y_{i}$, the dependent variable, is the logarithmic growth of real GDP per capita, $I F I_{i}$ denotes the average capital inflow to GDP ratio over the period under study, $\mathbf{X}_{i}$ a vector of control variables, $\varepsilon_{i}$ represents an i.i.d. stochastic term, and subscript $i$ indicates the countries, respectively. The vector of control variables always includes the logarithm of schooling and GDP per capita. To those we add the logarithm of period averages of inflation and the budget deficit in model (I); the initial investment ratio, the inflation rate and the budget deficit in model (II); the initial investment ratio and average population growth in model (III), while dropping the two policy variables.

The GMM dynamic panel estimation improves over the pure cross-section regression for several reasons. It uses both the cross-sectional and the time dimension of the data, increases the number of observations, controls for country-fixed effects and allows us to take the potential endogeneity of the regressors into account. Five year averages reduce the cyclicality of the data. The starting point for the dynamic panel estimation is the following growth regression:

$$
y_{i, t}-y_{i, t-1}=(\alpha-1) y_{i, t-1}+\beta I F I_{i, t}+\gamma^{\prime} \mathbf{X}_{i, t}+\eta_{i}+\varepsilon_{i, t},
$$

where $y_{i, t}$ is the logarithm of per capita income, $\mathbf{X}_{i, t}$ represents a set of weakly exogenous and predetermined control variables (as above), $\eta_{i}$ is a (time-invariant) countryspecific effect, and subscript $t$ indicates the time periods under consideration. We also

\footnotetext{
${ }^{4}$ Also an intermediate step, using two-stage instrumental variables regression, seems plausible (Edison et al., 2002). We experimented with a two-stage instrumental variable regression. Yet just like other authors, we found it hard to define suitable instruments as neither geographical distance nor legal origin seem suitable.
} 
include strictly exogenous time-dummies which are not reported to save space. Minor reformulation of equation (2) leads to a dynamic panel regression model of first order:

$$
y_{i, t}=\alpha y_{i, t-1}+\beta I F I_{i, t}+\gamma^{\prime} \mathbf{X}_{i, t}+\eta_{i}+\varepsilon_{i, t} .
$$

To eliminate the country specific effects $\eta_{i}$, the preceding equation is formulated in first differences:

$$
y_{i, t}-y_{i, t-1}=\alpha\left(y_{i, t-1}-y_{i, t-2}\right)+\beta\left(I F I_{i, t}-I F I_{i, t-1}\right)+\gamma^{\prime}\left(\mathbf{X}_{i, t}-\mathbf{X}_{i, t-1}\right)+\left(\varepsilon_{i, t}-\varepsilon_{i, t-1}\right) .
$$

The system GMM estimator, introduced by Arellano and Bover (1995) and Blundell and Bond (1997), combines the standard set of equations in first differences with suitably lagged levels as instruments with an additional set of equations in levels with suitable lagged first differences as instruments (Bond et al., 2001). ${ }^{5}$ Again, the application of the system GMM estimator for empirical growth analysis is in line with previous studies. We examined also the validity of the internal instruments and tested for serial correlation of the error term. ${ }^{6}$ A detailed econometric discussion can be found in Bond et al. (2001), Edison et al. (2002), and Fratzscher and Bussière (2004).

Our data for the contemporary period come from commonly used sources such as the World Development Indicator database (World Bank, 2004). Inflows of portfolio and equity capital over GDP are taken from the International Financial Statistics (IMF, 2005). Data on educational attainment (average years of schooling) are taken from the updated Barro-Leedataset (Barro and Lee, 2000). In total, we count observations for 54 countries for the contemporary period (1980-2002) covering a large number of developing and developed countries.

More demanding was the construction of the historical dataset. This effort would not have been possible without the support of numerous scholars. To a substantial extent, our dataset builds on three recently compiled datasets for the first era of financial globalization, namely those of Obstfeld and Taylor (2003), Clemens and Williamson (2004) and Ferguson and Schularick (2005). From these datasets come all data for schooling (primary school enrollment), the government balance and population growth. The data were collected by the authors both from primary and secondary sources. All real GDP data come from the seminal work of Angus Maddison (Maddison 1995, 2001).

Capital flow data are taken from the work by Stone (1999). It is important to note that the data from Stone cover only capital inflows from Great Britain which is the only country for which a detailed by-country breakdown of capital outflow data exists. However, Britain was by far the most important capital exporter of the time, trailed by a large distance by France and Germany. British data are thus very likely to be a reliable proxy for integration into the international capital market and are highly correlated with the overall stocks of international investment in 1914, which are available from different sources (Feis, 1965; Woodruff, 1966). The most challenging part consisted in collecting investment data for preWW1 period which are needed for our models (II) and (III). For many countries, we could

\footnotetext{
${ }^{5}$ We use the Stata "xtabond2" routine implemented by Roodman (2005) with the one-step robust estimator. Two-step estimation yielded analogous results.

${ }^{6}$ Test statistics are available from the authors on request.
} 
rely on Taylor (2002) and Jones and Obstfeld (1997). To these data we added information from Hofmann (2001) and partly relied on unpublished worksheets by Maddison (1992). A detailed data appendix is available from the authors on request.

In total, we have assembled data for 24 countries over 1880-1914 covering more than 80 percent of global GDP in $1914 .^{7}$ The historical dataset comprises of European countries (Austria-Hungary, Denmark, France, Germany, Greece, Italy, Norway, Portugal, Russia, Spain), North American and Australasian settler economies (Canada, USA, Australia, New Zealand) as well as South American (Argentina, Brazil, Chile, Mexico, Uruguay), Asian (Ceylon, India, Japan) and Middle Eastern (Egypt, Turkey/Ottoman Empire) economies.

As usual with historical data not all series are available for all countries across the different specifications in what constitutes an unbalanced panel. The summary statistics of both the contemporary and the historical dataset can be read from Table 1 .

Table 1: Summary statistics

\begin{tabular}{|c|c|c|c|c|}
\hline Variable & Mean & Std. Dev. & Min & Max \\
\hline \multicolumn{5}{|l|}{$1980-2002$} \\
\hline Growth $(1)$ & 0.091 & 0.114 & -0.318 & 0.477 \\
\hline Initial income & 8.696 & 0.979 & 6.314 & 10.381 \\
\hline Initial schooling & 0.408 & 0.740 & -2.244 & 1.748 \\
\hline Inflation rate & 0.022 & 0.013 & -0.032 & 0.074 \\
\hline Government balance & -0.034 & 0.043 & -0.201 & 0.162 \\
\hline Investment ratio & 0.240 & 0.069 & 0.109 & 0.601 \\
\hline Population growth & 0.016 & 0.010 & -0.002 & 0.057 \\
\hline Financial integration & 0.058 & 0.085 & -0.054 & 0.772 \\
\hline \multicolumn{5}{|l|}{$1880-1913$} \\
\hline Growth $^{(1)}$ & 0.046 & 0.074 & -0.357 & 0.347 \\
\hline Initial income & 7.276 & 0.631 & 5.700 & 8.627 \\
\hline Initial schooling & 0.071 & 0.013 & 0.024 & 0.087 \\
\hline Inflation rate & 0.014 & 0.040 & -0.084 & 0.351 \\
\hline Government balance & 0.010 & 0.031 & -0.070 & 0.180 \\
\hline Investment ratio & 0.135 & 0.052 & 0.030 & 0.325 \\
\hline Population growth & 0.013 & 0.008 & -0.005 & 0.047 \\
\hline Financial integration & 0.018 & 0.031 & 0.000 & 0.258 \\
\hline
\end{tabular}

(1) Mean of the growth rates of real GDP per capita over the 5-year periods in the sample.

\section{Results for the Contemporary Period}

As a first step we turn to the cross-sectional analysis of the period 1980-2002. We aim to reproduce the findings of Edison et al. (2002). As explained above, model (I) is an exact reproduction of their benchmark regression, albeit with data for two additional years (2001 and 2002). Model (II) adds the investment ratio and model (III) proxies a standard neoclassical growth model.

\footnotetext{
${ }^{7}$ Among the major economies, the only large country missing in the historical sample is China for which GDP series do not exist.
} 
Table 2: Cross-section estimation, 1980-2002

\begin{tabular}{lccc}
\hline \multicolumn{4}{l}{ Dependent variable: growth rate of real GDP per capita } \\
\hline Regression & $(1)$ & $(2)$ & $(3)$ \\
Empirical specification & Model (I) & Model (II) & Model (III) \\
\hline \hline Financial integration & $0.02^{* *}$ & 0.01 & 0.01 \\
& $(2.10)$ & $(1.01)$ & $(1.51)$ \\
Initial income & $-0.24^{* *}$ & $-0.21^{* *}$ & -0.32 \\
& $(2.36)$ & $(2.37)$ & $(1.00)$ \\
Initial schooling & $0.28^{* *}$ & $0.25^{\star *}$ & $0.19^{* *}$ \\
& $(2.30)$ & $(2.38)$ & $(2.10)$ \\
Inflation & $-0.02^{* *}$ & $-0.02^{*}$ & \\
& $(2.04)$ & $(1.95)$ & \\
Government balance & 0.01 & 0.01 & \\
& $(0.41)$ & $(0.20)$ & \\
Investment ratio & & $0.02^{*}$ & $0.02^{* *}$ \\
& & $(1.88)$ & $(2.65)$ \\
Population growth & & & $-0.23^{* * *}$ \\
& & & $(3.90)$ \\
Constant & $2.45^{* * *}$ & $1.79^{* *}$ & $2.87^{* * *}$ \\
& $(2.71)$ & $(2.31)$ & $(3.72)$ \\
\hline \# of obs. & 54 & 54 & 54 \\
$R^{2}$ (adj.) & 0.34 & 0.39 & 0.50 \\
\hline
\end{tabular}

Note: OLS with heteroskedasticity robust standard errors; t-values in brackets; * denotes statistical significance at the $10 \%,{ }^{* *}$ at the $5 \%$, $* * *$ at the $1 \%$-level.

Table 2 displays the results for the 54 countries in the modern sample. Regression (1) neatly reproduces the finding in Edison et al. (2002), because in the cross section there appears to be a significantly positive growth impact of international financial integration, measured via gross capital inflows to GDP. Also the other regressors are well behaved. There is evidence of conditional convergence, indicated by the negative sign of the coefficient attached to initial income, and also schooling as well as inflation carry the expected signs. In regressions (2) and (3), using the different models discussed above, the control variables keep the 'right' signs. However, the IFI-coefficient sees both its statistical significance and its impact on the growth rate greatly reduced. It no longer exerts significant influence on the per capita growth rate. Given the apparent sensitivity of the IFI-variable to changes in the specification, it would seem hardly justified to speak of a robust relationship between the two. 
Table 3: System GMM dynamic panel estimation, 1980-2002

\begin{tabular}{|c|c|c|c|}
\hline Regression & (4) & (5) & (6) \\
\hline Empirical specification & Model (I) & Model (II) & Model (III) \\
\hline Financial integration & $\begin{array}{c}0.10 \\
(0.30)\end{array}$ & $\begin{array}{l}-0.02 \\
(0.06)\end{array}$ & $\begin{array}{c}0.04 \\
(0.37)\end{array}$ \\
\hline Initial income & $\begin{array}{c}-0.02 \\
(1.18)\end{array}$ & $\begin{array}{c}-0.03 \\
(1.42)\end{array}$ & $\begin{array}{l}-0.01 \\
(0.55)\end{array}$ \\
\hline Initial schooling & $\begin{array}{c}0.02 \\
(0.77)\end{array}$ & $\begin{array}{c}0.04 \\
(1.32)\end{array}$ & $\begin{array}{l}0.06^{\star *} \\
(2.09)\end{array}$ \\
\hline Government balance & $\begin{array}{c}0.01 \\
(1.53)\end{array}$ & $\begin{array}{l}0.01^{* *} \\
(2.11)\end{array}$ & \\
\hline Inflation & $\begin{array}{l}-0.01 \\
(1.12)\end{array}$ & $\begin{array}{c}-0.01 \\
(0.74)\end{array}$ & \\
\hline Investment ratio & & $\begin{array}{c}0.33 \\
(1.52)\end{array}$ & $\begin{array}{l}0.40^{* *} \\
(2.26)\end{array}$ \\
\hline Population growth & & & $\begin{array}{c}0.07^{* * *} \\
(2.92)\end{array}$ \\
\hline Constant & $\begin{array}{c}0.23^{*} \\
(1.76) \\
\end{array}$ & $\begin{array}{c}0.18 \\
(1.12) \\
\end{array}$ & $\begin{array}{l}-0.32^{*} \\
(1.76) \\
\end{array}$ \\
\hline \# of obs. (\# of countries) & $225(54)$ & $225(54)$ & $265(54)$ \\
\hline
\end{tabular}

Yet, as discussed above, a cross-sectional analysis using OLS regressions could be biased if capital inflows were endogenous, i.e. determined by the growth rate of an economy. We therefore look at the dynamic panel estimation. The results are presented in Table 3 . They are consistent with much of the recent literature. Regression (4) reproduces the results by Edison et al. (2002) as it lends little support to the idea of an effect of financial openness on growth. Moreover, adding the investment ratio as an additional control variable in regression (5) the sign of the financial integration variable turns 'wrong'. Financial integration no longer enters the equation positively. Regression (6) eventually confirms that in a standard growth regression it seems impossible to identify a significantly positive influence of international financial integration on economic growth during the years 1980-2002. In the past two decades financially more integrated countries did not, on average, grow faster than closed economies.

\section{Results for the First Era of Financial Globalization}

Were things different in the first era of global finance? Table 4 presents the results of the cross-sectional regressions for the historical period. It suggests that the answer is affirmative. The results can be compared to those in Table 2, as we run identical OLS regressions on both datasets. We focus in our cross-sectional analysis of the historical period to the years 19001913 for which we dispose of the broadest dataset, but results for earlier sub-periods were also supportive.

In contrast to the mixed evidence in the contemporary period, the cross-sectional analysis of the historical period yields a less unambiguous relationship between financial openness and growth. Capital inflows to GDP appear as a significant growth driver in all three cross-sectional regressions, albeit the significance level is somewhat lower in regression (9). Given the small number of observations we are inclined not to read too much evidence into 
the cross-sectional results, but they certainly lend some support to the idea of a more robust relationship between international financial integration and growth in the first era of globalization. However, we are alerted that the cross-section may be misleading and thus look to the dynamic panel estimation for more conclusive evidence.

Table 4: Cross-section analysis, 1900-1913

\begin{tabular}{lccc}
\hline \multicolumn{4}{l}{ Dependent variable: growth rate of real GDP per capita } \\
\hline Regression & $(7)$ & $(8)$ & $(9)$ \\
Empirical specification & Model (I) & Model (II) & Model (III) \\
\hline \hline Financial integration & $0.28^{\star * *}$ & $0.26^{\star * *}$ & $0.23^{*}$ \\
& $(3.55)$ & $(3.60)$ & $(1.77)$ \\
Initial income & 0.00 & 0.06 & 0.07 \\
& $(0.05)$ & $(1.46)$ & $(1.39)$ \\
Initial schooling & $0.06^{\star * *}$ & 0.01 & -0.01 \\
& $(2.98)$ & $(0.10)$ & $(0.41)$ \\
Inflation & 0.01 & 0.01 & \\
& $(1.42)$ & $(1.36)$ & \\
Government balance & 0.01 & -0.04 & \\
& $(0.32)$ & $(0.96)$ & \\
Investment ratio & & 0.63 & 0.60 \\
& & $(1.47)$ & $(1.12)$ \\
Population growth & & & 0.01 \\
& & & $(0.19)$ \\
Constant & $-0.37^{*}$ & $-0.34^{*}$ & -0.36 \\
& $(1.79)$ & $(2.05)$ & $(1.45)$ \\
\hline \# of obs. & 21 & 16 & 19 \\
$R^{2}$ (adj.) & 0.55 & 0.62 & 0.52 \\
\hline
\end{tabular}

Note: OLS with heteroskedasticity robust standard errors; t-values in brackets; $*$ denotes statistical significance at the $10 \%, * *$ at the $5 \%$, $* * *$ at the $1 \%$-level.

The results of the dynamic panel estimation are presented in Table 5. We start again by running the base model from Edison et al. (2002). Regression (10) shows that also the dynamic panel model yields a highly significant effect of international financial integration on growth. Recall that the identical regression with data for the years 1980-2002 failed to exhibit a robust link. The control variables remain well-behaved and enter with the 'right' sign. There is evidence of conditional convergence and also the human capital proxy is strongly significant.

The degree of international financial integration also remains a significant growth driver in regressions (11) and (12) which implement the two other models presented above. The statistical significance declines somewhat if the investment ratio and population growth are added as regressors, but stays above the 5\% and $10 \%$-levels. It is the inclusion of population growth, which enters the historical regression with a positive sign, that drags down the growth effect of financial integration.

Summing up, we have run identical regressions on the contemporary and historical datasets to examine the financial integration-growth nexus. Our regressions indicate that before WW1 international financial integration spurred economic growth, whereas there is little evidence of a comparable effect in recent decades. In addition, this finding appears robust over a number of different specifications. How can we thus explain that financial 
integration apparently contributed to growth in the first era of financial globalization, but no longer today? The following section presents a potential explanation for this observation.

Table 5: System GMM dynamic panel estimation, 1880-1913

\begin{tabular}{lccc}
\hline \multicolumn{4}{l}{ Dependent variable: growth rate of real GDP per capita } \\
\hline Regression & $(10)$ & $(11)$ & $(12)$ \\
Empirical specification & Model (I) & Model (II) & Model (III) \\
\hline \hline Financial integration & $0.04^{* * *}$ & $0.06^{* *}$ & $0.04^{*}$ \\
& $(2.75)$ & $(2.11)$ & $(1.97)$ \\
Initial income & $-0.03^{*}$ & -0.02 & $-0.04^{*}$ \\
& $(1.88)$ & $(0.70)$ & $(2.06)$ \\
Initial schooling & $0.03^{* * *}$ & 0.02 & $0.04^{* *}$ \\
& $(4.81)$ & $(1.28)$ & $(2.29)$ \\
Government balance & -0.04 & -0.07 & \\
& $(1.53)$ & $(1.10)$ & \\
Inflation & -0.003 & -0.001 & \\
& $(1.06)$ & $(0.27)$ & \\
Investment ratio & & -0.09 & -0.21 \\
& & $(0.40)$ & $(1.60)$ \\
Population growth & & & 0.01 \\
& & & $(0.73)$ \\
Constant & 0.04 & 0.07 & 0.06 \\
& $(0.57)$ & $(0.65)$ & $(1.54)$ \\
\hline \# of obs. (\# of countries) & $141(24)$ & $93(17)$ & $107(19)$ \\
\hline
\end{tabular}

Note: Arellano-Bond dynamic panel estimation, robust one-step system GMM results; t-values in brackets; * denotes statistical significance at the $10 \%, * *$ at the $5 \%, * * *$ at the $1 \%$-level.

\section{Discussion of the Main Results}

\subsection{Preliminary Thoughts}

The main finding of the preceding section was that international financial integration promoted economic growth in the first era of globalization but fails to do so in modern times. How can we explain this phenomenon? We aim to sketch a preliminary answer to the question. In a nutshell, we argue that the standard neoclassical textbook model provides a better description of the real world for the historical era than it does for the modern period. In other words, the neoclassical model works better for the historical period, because the very prerequisites for it to work properly were in place back then, but are no longer today. This conclusion rests on four (interdependent) observations:

(1) It is very likely that the quality of institutions, especially the assignment and enforcement of property rights, was higher in a number of countries (belonging to net capital importers) than it is today. For instance, Lucas (1990, pp. 94/95) argues: ${ }^{8}$

Until around 1945, much of the Third World was subject to European-imposed legal and economic arrangements, and had been so for decades or even centuries. A European lending to a borrower in India or the Dutch East Indies could expect

\footnotetext{
${ }^{8}$ For a similar line of reasoning see Ferguson (2003).
} 
his contract to be enforced with exactly the same effectiveness and by exactly the same means as a contract with domestic borrowers.

The importance of this point for the favored reasoning is reinforced by the comprehensive empirical study of Alfaro et al. (2003), who aim to resolve the Lucas paradox in modern times. Employing cross-country data for 50 countries over 1971-1998 they find that institutional quality is the most important variable in explaining the paucity of rich-poor capital flows.

(2) The historical period under study spans the time of the international gold standard. This monetary system produced a comparably stable internal (inflation rate) and external (exchange rate) monetary environment. Despite the fact that the gold standard did not give rise to strict price stability, as argued by Cooper (1982), it brought a number of countries comparably stable monetary conditions, especially when contrasted with the experiences of most developing countries in the post-WW2 period. $^{9}$ In addition, the frequency of exchange rate crises was much smaller during that time (Eichengreen, 2002).

The fulfillment of the two preceding premises is an implicit but necessary condition for the textbook neoclassical model to work properly. As a consequence, the patterns of capital mobility in the historical period were markedly different from what we observe in the contemporary world economy:

(3) Net capital movements were higher in the historical era than they are today. A standard way to examine de facto capital mobility is the Feldstein-Horioka (1980) test. Numerous applications of this test produced ample empirical evidence that capital mobility was indeed much higher in the period 1870-1914 compared to the post-WW2 period (Bayoumi, 1990; Eichengreen, 1990; Taylor, 1996; Obstfeld and Jones, 1997).

(4) In the first era of financial globalization, gross capital flows to peripheral countries (about $2 \%$ of GDP on average, as documented in Table 1) gave rise to substantial net capital movements. The modern period is also characterized by massive gross capital flows, but they do not translate into substantial net capital flows from rich to poor regions. In the pre-1914 boom, there was little difference between net flows and gross flows because most flows were uni-directional from the rich core to the poor periphery (Obstfeld and Taylor, 2004). Post 1970, however, gross flows (both inflows and outflows) increased tremendously. But net flows (inflows minus outflows) held constant at relatively low levels for the last thirty years. Most international capital flows nowadays take place between rich countries (north-north as opposed to north-south). Obstfeld and Taylor (2004) conclude that contemporary financial globalization is more characterized by "diversification finance" not by "development finance".

As a result, the Lucas paradox of missing rich-poor capital flows was less pronounced in the first era of globalization. While Clemens and Williamson (2004) find that the Lucas paradox was as strong before 1914, other studies have questioned this result and pointed to a much less pronounced "wealth bias" in international capital flows before WW1 (Obstfeld and Taylor, 2004; Schularick, 2005). This mirrors the earlier findings by Edelstein (1982), who showed that the historical period was associated with substantial investment flows from continental Europe to overseas areas.

In summary, one can argue that international capital market integration significantly fostered economic growth in the historical episode because of the combination of two key factors: First, there were tremendous investment opportunities in regions where financial

\footnotetext{
${ }^{9}$ Table 1 shows an average inflation rate which is nearly twice as large for the modern period compared to the historical period. It is true that it is more the variability if the inflation rate rather than its level which represents a problem. However, the variability and the level of inflation are typically highly correlated.
} 
funds were scarce. Second, a favorable institutional setting and a comparably stable monetary environment were secured, so that the prerequisites for the textbook model to work properly were given. Taken together, these two factors gave rise to substantial net capital flows from the rich core to the poor periphery that contributed to the observed growth effect of international financial integration in the first era of global finance.

\subsection{A Simple Model with Imperfect Property Rights}

That financial globalization can have had markedly different effects on economic growth in the two eras of international capital market integration can be illustrated through a fairly simple neoclassical model that integrates imperfect property rights. Consider a perfectly competitive economy populated by a continuum of mass one of identical firms and households. Firms produce a homogenous good according to:

$$
Y_{i}^{j}=\left(K_{i}^{j}\right)^{\alpha}\left(N_{i}^{j}\right)^{\beta}\left(L_{i}^{j}\right)^{1-\alpha-\beta}
$$

where $Y_{i}^{j}$ is final output, taken as the numeraire, produced by firm $i \in[0,1]$ in country $j \in\{1,2\}, K_{i}^{j}, N_{i}^{j}$ and $L_{i}^{j}$ denote capital, labor and land employed by firm $i$ in country $j$, $0<\alpha, \beta<1$ and $0<\alpha+\beta<1$. In this economy individual output $Y_{i}^{j}$ equals average output given by $Y^{j}=\left(K^{j}\right)^{\alpha}\left(N^{j}\right)^{\beta}\left(L^{j}\right)^{1-\alpha-\beta}$, which also equals aggregate output. Moreover, we assume that the supply of labor and land is fixed in every country and that labor is immobile internationally. To simplify matters and without loss of generality, we can set $\left(N_{i}^{j}\right)^{\beta}\left(L_{i}^{j}\right)^{1-\alpha-\beta}$ equal to unity for both countries.

Turning to property rights protection, we assume that output produced by an individual firm is insecure in that firm $i$ 's claim to his own output can be contested by other firms, and $i$ in turn may contest the claims of others to their production. For simplicity this process is modeled by imagining that firms compete against the economy-wide average and that individual output is reallocated according to an exogenous sharing rule indicated by $0<\mu^{j}<1 .{ }^{10}$ The gross revenue of the representative firm accordingly reads:

$$
Y_{i}^{j}=\mu^{j}\left(K_{i}^{j}\right)^{\alpha}+\left(1-\mu^{j}\right)\left(K^{j}\right)^{\alpha}
$$

Note that the term $\left(K_{i}^{j}\right)^{\alpha}$ represents individual output of firm $i$ in country $j$, whereas $\left(K^{j}\right)^{\alpha}$ stands for the average output of economy $j$. Profit maximization implies: $r_{i}^{j}=\mu^{j} \alpha Y^{j} / K^{j}, w_{i}^{j}=\mu^{j} \beta Y^{j} / N^{j}$, and $p_{i}^{j}=\mu^{j}(1-\alpha-\beta) Y^{j} / L^{j}$, where $r_{i}^{j}, w_{i}^{j}$, and $p_{i}^{j}$ denote the rental price of capital, the wage rate and rental price of land, respectively.

Capital goods (as well as land) are owned by households and rented to firms. In addition, households are the owners of the firms. Income of the typical household $I_{i}^{j}$ reads:

\footnotetext{
${ }^{10}$ This is similar to Gonzàlez $(2004,2005)$, where $\mu^{j}$ is endogenously determined by investments in defensive and offensive capital.
} 


$$
I_{i}^{j}=r^{j} K_{i}^{j}+w^{j} N_{i}^{j}+p^{j} L_{i}^{j}+\left(1-\mu^{j}\right)\left(K^{j}\right)^{\alpha}=Y_{i}^{j}=Y^{j} .
$$

Both economies are perfectly identical except for two aspects: First, the initial capital endowment, relative to labor and land, might diverge. Second, the extent of property rights protection, given by $\mu^{j}$, might also be different. Finally, it is important to note that equation (6) can also be interpreted as a shortcut formulation which captures the redistributive effects of unexpected inflation or unexpected exchange rate changes. This is to say that by redistributing the revenue of economic activities from one individual to another, weak property rights and an unstable monetary environment are very similar. This completes the description of the model.

We now compare world output under autarky to world output under capital market integration. World output under autarky $Y_{a}^{w}$ is given by:

$$
Y_{a}^{w}=\left(K_{a}^{1}\right)^{\alpha}+\left(K_{a}^{2}\right)^{\alpha}
$$

where $K_{a}^{1}$ and $K_{a}^{2}$ denote the capital stock in economy 1 and 2 under autarky. In contrast, world output under international capital mobility $Y_{g}^{w}$ reads:

$$
Y_{g}^{w}=\left(K_{g}^{1}\right)^{\alpha}+\left(K_{g}^{2}\right)^{\alpha}
$$

where $K_{g}^{1}$ and $K_{g}^{2}$ denote the amount of capital allocated to economy 1 and 2 under capital market integration. The international allocation of the global capital stock $K^{w}$ is determined by the equilibrium condition $r^{1}=r^{2}$, which implies:

$$
\mu^{1} \alpha \frac{Y^{1}}{K_{g}^{1}}=\mu^{2} \alpha \frac{Y^{2}}{K_{g}^{2}} .
$$

Taking $K^{w}:=K_{g}^{1}+K_{g}^{2}$ into account, the solution for $K_{g}^{1}$ and $K_{g}^{2}$ reads as follows:

$$
\begin{aligned}
& K_{g}^{1}=\frac{K^{w}}{1+\left(\mu^{1}\right)^{\frac{1}{\alpha-1}}\left(\mu^{2}\right)^{\frac{1}{1-\alpha}}}, \\
& K_{g}^{2}=\frac{K^{w}}{1+\left(\mu^{1}\right)^{\frac{1}{1-\alpha}}\left(\mu^{2}\right)^{\frac{1}{\alpha-1}}} .
\end{aligned}
$$

For instance, if both economies exhibit the same extent of property rights protection, i.e. $\mu^{1}=\mu^{2}$, then the international allocation of capital is $K_{g}^{1}=K_{g}^{2}=0.5 K^{w}$. 
We are now in the position to answer the following question: How does the world output change in response to capital market integration? It can be shown that the ratio of world output under integration and world output under autarky can be expressed as follows:

$$
\frac{Y_{g}^{w}}{Y_{a}^{w}}=\frac{\left[\left(1+\gamma^{\frac{1}{1-\alpha}}\right)^{-\alpha}+\left(1+\gamma^{\frac{1}{\alpha-1}}\right)^{-\alpha}\right](1+\lambda)^{\alpha}}{1+\lambda^{\alpha}}
$$

where $\gamma:=\mu^{1} / \mu^{2}$ and $\lambda:=K_{a}^{1} / K_{a}^{2}$. The preceding expression shows that, in the simple model under study, relative world output depends on two key parameters, namely the relative quality of property rights $\gamma$ and the relative initial capital endowment $\lambda$. By assuming that the capital share is $\alpha=0.45$ (which is consistent with a broad concept of capital, including partly human capital), the consequences of capital market integration for world output can be illustrated by Figure 1.

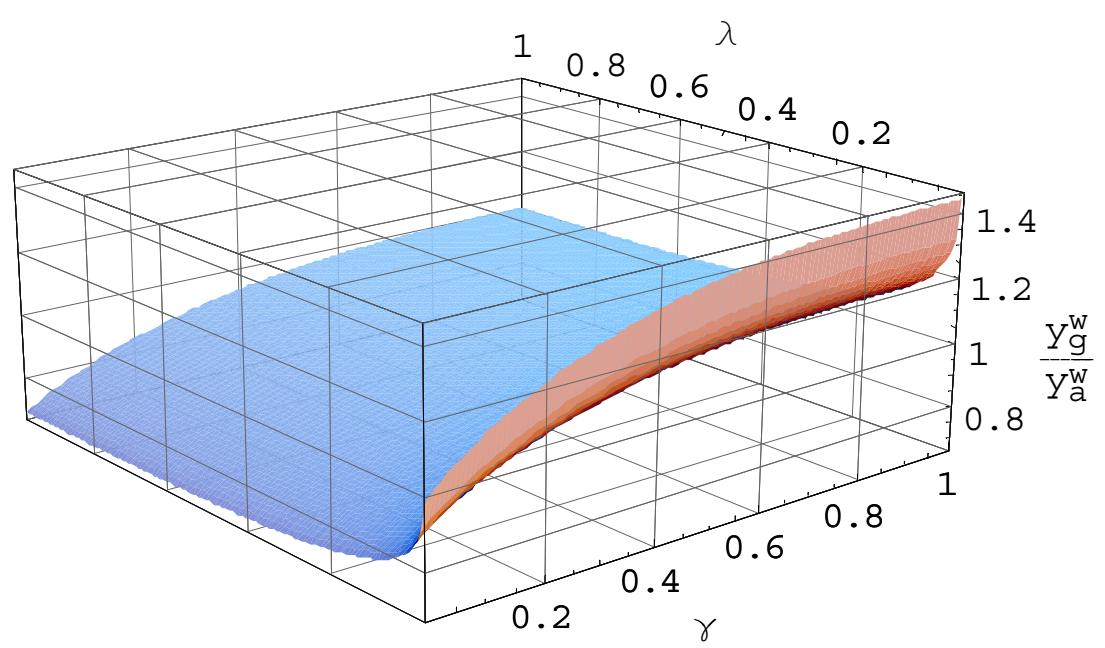

Figure 1: Relative world output as a function of $\gamma$ and $\lambda$ (assuming $\alpha=0.45$ ).

Provided that both economies are initially endowed with the same stock of capital (relative to labor and land), i.e. $\lambda=1$, and assuming that the extent of property rights protection is identical in both economies, i.e. $\gamma=1$, capital market integration does not exert a positive output effect, i.e. $Y_{g}^{w} / Y_{a}^{w}=1$. $^{11}$ Now if initial endowments differ strongly, i.e. $\lambda$ is very small, and property rights protection is fairly similar in both economies, i.e. $\gamma$ is near unity, capital market integration has a strong positive impact on world output. In the numerical example illustrated in Figure 1 this increase amounts to about $40 \%$. This constellation captures the basic characteristics of the historical period. On the other hand, the modern period is also characterized by a substantial difference in initial capital endowments, i.e. $\lambda$ is low. However, it appears evident that there is a large differential in property rights protection, i.e. $\gamma$ is low. For this constellation, the model under study predicts either a negligible or even a negative output effect.

\footnotetext{
11 It is unsurprising that the integration of two identical neoclassical economies does not have an effect on growth. This would be different with endogenous growth models exhibiting scale effects due to knowledge spillovers (Bretschger and Steger, 2004).
} 
This last observation is, of course, a typical second-best result. In the presence of a strong distortion (i.e. a large differential in property rights protection), the removal of a second market imperfection (i.e. the removal of barriers to capital mobility) may even worsen the situation in the sense of reducing world output. Finally, it should be noted that the simplistic model under study implies an immediate adjustment of the international capital allocation and therefore an instantaneous change in world output. In reality, this process would be distributed over time due to the presence of capital adjustments costs. Hence, the model is capable of capturing the basic effects of capital market integration for transitional output growth.

\section{Summary and Conclusion}

Considerable empirical effort has been devoted to investigate whether international financial integration boosts economic growth. The overall result of these studies, which primarily focused on the post-WW2 period, was that there are little indications of a robust growth effect of international financial integration. On the other hand, there is substantial narrative evidence from economic history that highlights the contribution European capital made to economic growth of peripheral economies before 1914. In this paper, we have investigated empirically the nexus between international financial integration and economic growth for the pre-WW1 period. We have used the same empirical models and the same econometric techniques as recent studies allowing for a high degree of comparability with previous work for the contemporary period. Our results suggest that international capital market integration fostered economic growth significantly in the historical period, but no longer does so today.

Our preliminary explanation of these diverse experiences is very simple. We think that the neoclassical model provides a valid description of the historical period, but appears unsuitable to explain the contemporary world economy. In particular, we argue that the historical period, in stark contrast to the post-WW2 period, was characterized by: (i) low differentials in property rights protection between countries; (ii) a (comparably) stable monetary environment; (iii) a higher degree of net capital mobility, as measured by the Feldstein-Horioka criterion; and (iv) substantial (net) capital movements from rich (core) to poor (peripheral) regions.

Our results reinforce the conclusion that those economies which open themselves to the world economy need at first abolish domestic distortions to reap the benefits of globalization. More specifically, it seems especially important to establish good property rights in all economies participating in the world economy. This line of reasoning is a straightforward application and reinforces the importance of the well-known second-best theorem. 


\section{References}

Alfaro, L., S. Kalemli-Ozcan and V. Volosovych (2003). "Why doesn't capital flow from rich to poor countries? An empirical investigation" Harvard Business School Working Paper, No. $\underline{04-040 .}$

Arnello, M and O. Bover (1995). "Another Look at the Instrumental Variable Estimation of Error-Components Models.” Journal of Econometrics 68 (1): 29-51.

Arteta, C., B. Eichengreen, C. Wyplosz (2001). "When Does Capital Account Liberalization Help More Than It Hurts?" Manuscript, University of California at Berkeley.

Barro, R. J. and J.-W. Lee (2000). "International Data on Educational Attainment: Updates and Implications." CID Working Paper No. 42. http://www.cid.harvard.edu/cidwp/042.htm

Barro, R. J. and X. Sala-i-Martin (1992), "Convergence", Journal of Political Economy, 100, 21, 223-251.

Bayoumi, T. (1990). “Saving-Investment Correlations”, IMF Staff Papers, 37, 360-87.

Bekaert, G., R. Harvey, C. Lundblad (2001). "Does Financial Liberalization Spur Growth?" NBER Working Paper No. 8245.

Bhagwati, J. (1998). "The Capital Myth." Foreign Affairs 77 (3): 7-12.

Blundell, R. and S. Bond (1997). "Initial Conditions and Moment Resrictions in Dynamic Panel Data Models." University College London Discussion Papers in Economics 97/7.

Bond, Stephen, Anke Hoeffler, and Jonathan Temple (2001), GMM estimation of empirical growth models, Working Paper, University of Bristol.

Bordo, M., A. M. Taylor, et al., Eds. (2003). "Globalization in Historical Perspective" National Bureau of Economic Research Conference Report. Chicago, University of Chicago Press.

Bretschger, L. and T. M. Steger, The Dynamics of Economic Integration: Theory and Policy, International Economics and Economic Policy, 2004, 1 (2-3), 119-134.

Clemens, M. A. and J. Williamson (2004). "Wealth Bias in the First Global Capital Market Boom." Economic Journal 114 (2): 304-337.

Cooper, R. (1982). "The Gold Standard: Historical Facts and Future Prospects." Brooking Papers on Economic Activity, Vol. 1, 1-45.

Edelstein, M. (1982). "Overseas Investment in the Age of High Imperialism, The United Kingdom 1850-1914.” Columbia University Press, 1982.

Edison, H., R. Levine, L. Ricci, and T. Slok (2002). "International Financial Integration and Economic Growth." Journal of International Money and Finance, vol. 21(6), 749-776.

Edison, H., M. W. Klein, L. Ricci, and T. Slok (2004). "Capital Account Liberalization and 
Economic Performance: Survey and Synthesis." IMF Staff Papers, Vol. 51, No. 2, 220-256.

Edwards, S. (2001). "Capital Mobility and Economic Performance: Are Emerging Economies Different?" NBER Working Paper No. 8076 (January).

Eichengreen, B. (2002). “International Financial Crises: Is the Problem Growing?" Jahrbuch für Wirtschaftsgeschichte 1: 89-104.

Eichengreen, B. (2001). "Capital Account Liberalization: What Do the Cross-Studies Tell Us?" World Bank Economic Review, October 2001; 15: 341-65.

Eichengreen, B. (1990). "Trends and Cycles in Foreign Lending." In: Capital Flows in the World Economy, H. Siebert (ed.), Tübingen, Mohr-Siebeck.

Eichengreen, B. and D. Leblang (2003). "Capital Account Liberalization and Growth: Was Mr. Mahatir Right?" International Journal of Finance and Economics 8: 205-224.

Feis, H. (1965). Europe The World's Banker 1870-1914. WW Norton, New York.

Feldstein, M. S. and C. Y. Horioka (1980). "Domestic Saving and International Capital Flows." Economic Journal 90: 314-329.

Ferguson, N. and M. Schularick (forthcoming). "The Empire Effect: The Determinants of Country Risk in the First Era of Financial Globalization." Journal of Economic History.

Ferguson, N. (2003). "British Imperialism Revised: The Costs and Benefits of 'Anglobalization"” Development Research Institute Working Paper Series No. 2.

Fratzscher, M. and M. Bussiere (2004). "Financial Openness and Growth: Short-Run Gain, Long-Run Gain?" European Central Bank Working Paper No. 348.

González, Francisco M. and Hugh M. Neary, "Optimal Growth Policy Under Privately Enforced Property Rights", Working Paper UBC, 2004, Vancouver.

González, Francisco M., "Effective Property Rights, Conflict and Growth", Working Paper $\underline{\mathrm{UBC}}, 2005$, Vancouver.

Grilli, Vittorio, and Gian Maria Milesi-Ferretti (1995). "Economic Effects and Structural Determinants of Capital Controls," Staff Papers, International Monetary Fund, 42 (September): 517-51.

Hofman, André, "The Economic Development of Latin America in the Twentieth Century". Northampton, MA: Edward Elgar Publishing, 2000.

International Monetary Fund (2005), "International Financial Statistics". Electronic version, accessed via Research Time Series Database (ReTIS 3.2) at Deutsche Bank Research.

Jones, T. and M. Obstfeld, M. (1997). "Saving, Investment, and Gold: A Reassessment of Historical Current Account Data.” NBER Working Paper 6103.

Klein, M. W. (2005). "Capital Account Liberalization, Institutional Quality and Economic 
Growth: Theory and Evidence." Manuscript, Fletcher School of Law and Diplomacy.

Klein, M. W. and G. P. Olivei (2001). "Capital Account Liberalization, Financial Depth and Economic Growth." Manuscript Fletcher School of Law and Diplomacy.

Kraay A. 1998. In search of the macroeconomic effects of capital account liberalization Manuscript, World Bank, Washington, DC.

Levine, R. (2001). "International Financial Liberalization and Economic Growth." Review of International Economics 9: 668-702.

Levine, R. and D. Renelt (1992). "A Sensitivity Analysis of Cross-Country Growth Regressions." American Economic Review 82(4): 942-963.

Lucas, R. (1990). "Why Doesn't Capital Flow From Rich to Poor Countries?" American Economic Review 80: 93-96.

Maddison, A. (2003). The World Economy: Historical Statistics. Paris, OECD.

Maddison, A. (2001). The World Economy. A Millennial Perspective. Paris, OECD.

Maddison, A. (1995). The World Economy: A Millennial Perspective. Paris, OECD

Maddison, A. (1992). "A Long Run Perspective on Saving." $\underline{\text { Scandinavian Journal of }}$ Economics 94 (2): 181-196.

McLean, B. and S. Shrestha (2002). "International Financial Liberalisation and Economic Growth." Reserve Bank of Australia, Research Discussion Paper.

Obstfeld, M., Risk-Taking, Global Diversification, and Growth, American Economic Review, 1994, Vol. 85, No. 5, 1310-1329.

Obstfeld, M. and Alan M. Taylor (2004). "Global capital markets: integration, crisis, and growth.” Cambridge, Cambridge University Press.

Obstfeld, M. and A. M. Taylor (2003). "Sovereign Risk, Credibility and the Gold Standard: 1870-1913 vs. 1925-1931." Economic Journal 113: 241-275.

Prasad, E., K. Rogoff, S.-J. Wei, M. A. Kose. (2003). Effects of Financial Globalization on Developing Countries. Washington, D.C., International Monetary Fund.

Quinn, Dennis (1997). "The correlates of change in international financial regulation," American Political Science Review 91 (3): 531-551.

Rodrik, D., Ed. (1998). "Who Needs Capital-Account Convertibility?" Princeton Studies in International Finance. Princeton, Princeton University Press.

Roodman, D. (2005). "XTABOND2: Stata module to extend xtabond dynamic panel data estimator." http://ideas.repec.org/c/boc/bocode/s435901.html

Schularick, M. (2005). “A Tale of Two 'Globalizations’: Capital Flows From Rich to Poor in 
Two Eras of Global Finance." International Journal of Finance and Economics (forthcoming).

Stiglitz, J. E. (2000). "Capital Market Liberalization, Economic Growth, and Instability." World Development 28 (6): 1075-1086.

Stone, I. (1999). “The Global Export of Capital from Great Britain.” London, Macmillan.

Taylor, A. M. (2002). "A Century of Current Account Dynamics." Journal of International Money and Finance 21 (November 2002): 725-48.

Taylor, A. M. (1996). "International Capital Mobility: The Saving-Investment Relationship." NBER Working Paper 5743.

Twomey, M. J. (2000). “A Century of Foreign Investment in the Third World." London, Routledge.

Woodruff, W. (1966). “The Impact of Western Man.” London, Macmillan.

World Bank (2004). “World Development Indicators.” Washington, World Bank. 


\section{CESifo Working Paper Series}

(for full list see www.cesifo-group.de)

1629 Torberg Falch and Bjarne Strøm, Wage Bargaining and Political Strength in the Public Sector, December 2005

1630 Hartmut Egger, Peter Egger, Josef Falkinger and Volker Grossmann, International Capital Market Integration, Educational Choice and Economic Growth, December 2005

1631 Alexander Haupt, The Evolution of Public Spending on Higher Education in a Democracy, December 2005

1632 Alessandro Cigno, The Political Economy of Intergenerational Cooperation, December 2005

1633 Michiel Evers, Ruud A. de Mooij and Daniel J. van Vuuren, What Explains the Variation in Estimates of Labour Supply Elasticities?, December 2005

1634 Matthias Wrede, Health Values, Preference Inconsistency, and Insurance Demand, December 2005

1635 Hans Jarle Kind, Marko Koethenbuerger and Guttorm Schjelderup, Do Consumers Buy Less of a Taxed Good?, December 2005

1636 Michael McBride and Stergios Skaperdas, Explaining Conflict in Low-Income Countries: Incomplete Contracting in the Shadow of the Future, December 2005

1637 Alfons J. Weichenrieder and Oliver Busch, Artificial Time Inconsistency as a Remedy for the Race to the Bottom, December 2005

1638 Aleksander Berentsen and Christopher Waller, Optimal Stabilization Policy with Flexible Prices, December 2005

1639 Panu Poutvaara and Mikael Priks, Violent Groups and Police Tactics: Should Tear Gas Make Crime Preventers Cry?, December 2005

1640 Yin-Wong Cheung and Kon S. Lai, A Reappraisal of the Border Effect on Relative Price Volatility, January 2006

1641 Stefan Bach, Giacomo Corneo and Viktor Steiner, Top Incomes and Top Taxes in Germany, January 2006

1642 Johann K. Brunner and Susanne Pech, Optimum Taxation of Life Annuities, January 2006

1643 Naércio Aquino Menezes Filho, Marc-Andreas Muendler and Garey Ramey, The Structure of Worker Compensation in Brazil, with a Comparison to France and the United States, January 2006 
1644 Konstantinos Angelopoulos, Apostolis Philippopoulos and Vanghelis Vassilatos, RentSeeking Competition from State Coffers: A Calibrated DSGE Model of the Euro Area, January 2006

1645 Burkhard Heer and Bernd Suessmuth, The Savings-Inflation Puzzle, January 2006

1646 J. Stephen Ferris, Soo-Bin Park and Stanley L. Winer, Political Competition and Convergence to Fundamentals: With Application to the Political Business Cycle and the Size of Government, January 2006

1647 Yu-Fu Chen, Michael Funke and Kadri Männasoo, Extracting Leading Indicators of Bank Fragility from Market Prices - Estonia Focus, January 2006

1648 Panu Poutvaara, On Human Capital Formation with Exit Options: Comment and New Results, January 2006

1649 Anders Forslund, Nils Gottfries and Andreas Westermark, Real and Nominal Wage Adjustment in Open Economies, January 2006

1650 M. Hashem Pesaran, Davide Pettenuzzo and Allan G. Timmermann, Learning, Structural Instability and Present Value Calculations, January 2006

1651 Markku Lanne and Helmut Luetkepohl, Structural Vector Autoregressions with Nonnormal Residuals, January 2006

1652 Helge Berger, Jakob de Haan and Jan-Egbert Sturm, Does Money Matter in the ECB Strategy? New Evidence Based on ECB Communication, January 2006

1653 Axel Dreher and Friedrich Schneider, Corruption and the Shadow Economy: An Empirical Analysis, January 2006

1654 Stefan Brandauer and Florian Englmaier, A Model of Strategic Delegation in Contests between Groups, January 2006

1655 Jan Zápal and Ondřej Schneider, What are their Words Worth? Political Plans and Economic Pains of Fiscal Consolidations in New EU Member States, January 2006

1656 Thiess Buettner, Sebastian Hauptmeier and Robert Schwager, Efficient Revenue Sharing and Upper Level Governments: Theory and Application to Germany, January 2006

1657 Daniel Haile, Abdolkarim Sadrieh and Harrie A. A. Verbon, Cross-Racial Envy and Underinvestment in South Africa, February 2006

1658 Frode Meland and Odd Rune Straume, Outsourcing in Contests, February 2006

1659 M. Hashem Pesaran and Ron Smith, Macroeconometric Modelling with a Global Perspective, February 2006 
1660 Alexander F. Wagner and Friedrich Schneider, Satisfaction with Democracy and the Environment in Western Europe - a Panel Analysis, February 2006

1661 Ben J. Heijdra and Jenny E. Ligthart, Fiscal Policy, Monopolistic Competition, and Finite Lives, February 2006

1662 Ludger Woessmann, Public-Private Partnership and Schooling Outcomes across Countries, February 2006

1663 Topi Miettinen and Panu Poutvaara, Political Parties and Network Formation, February 2006

1664 Alessandro Cigno and Annalisa Luporini, Optimal Policy Towards Families with Different Amounts of Social Capital, in the Presence of Asymmetric Information and Stochastic Fertility, February 2006

1665 Samuel Muehlemann and Stefan C. Wolter, Regional Effects on Employer Provided Training: Evidence from Apprenticeship Training in Switzerland, February 2006

1666 Laszlo Goerke, Bureaucratic Corruption and Profit Tax Evasion, February 2006

1667 Ivo J. M. Arnold and Jan J. G. Lemmen, Inflation Expectations and Inflation Uncertainty in the Eurozone: Evidence from Survey Data, February 2006

1668 Hans Gersbach and Hans Haller, Voice and Bargaining Power, February 2006

1669 Françoise Forges and Frédéric Koessler, Long Persuasion Games, February 2006

1670 Florian Englmaier and Markus Reisinger, Information, Coordination, and the Industrialization of Countries, February 2006

1671 Hendrik Hakenes and Andreas Irmen, Something out of Nothing? Neoclassical Growth and the 'Trivial' Steady State, February 2006

1672 Torsten Persson and Guido Tabellini, Democracy and Development: The Devil in the Details, February 2006

1673 Michael Rauber and Heinrich W. Ursprung, Evaluation of Researchers: A Life Cycle Analysis of German Academic Economists, February 2006

1674 Ernesto Reuben and Frans van Winden, Reciprocity and Emotions when Reciprocators Know each other, February 2006

1675 Assar Lindbeck and Mats Persson, A Model of Income Insurance and Social Norms, February 2006

1676 Horst Raff, Michael Ryan and Frank Staehler, Asset Ownership and Foreign-Market Entry, February 2006 
1677 Miguel Portela, Rob Alessie and Coen Teulings, Measurement Error in Education and Growth Regressions, February 2006

1678 Andreas Haufler, Alexander Klemm and Guttorm Schjelderup, Globalisation and the Mix of Wage and Profit Taxes, February 2006

1679 Kurt R. Brekke and Lars Sørgard, Public versus Private Health Care in a National Health Service, March 2006

1680 Dominik Grafenhofer, Christian Jaag, Christian Keuschnigg and Mirela Keuschnigg, Probabilistic Aging, March 2006

1681 Wladimir Raymond, Pierre Mohnen, Franz Palm and Sybrand Schim van der Loeff, Persistence of Innovation in Dutch Manufacturing: Is it Spurious?, March 2006

1682 Andrea Colciago, V. Anton Muscatelli, Tiziano Ropele and Patrizio Tirelli, The Role of Fiscal Policy in a Monetary Union: Are National Automatic Stabilizers Effective?, March 2006

1683 Mario Jametti and Thomas von Ungern-Sternberg, Risk Selection in Natural Disaster Insurance - the Case of France, March 2006

1684 Ken Sennewald and Klaus Waelde, "Itô's Lemma" and the Bellman Equation for Poisson Processes: An Applied View, March 2006

1685 Ernesto Reuben and Frans van Winden, Negative Reciprocity and the Interaction of Emotions and Fairness Norms, March 2006

1686 Françoise Forges, The Ex Ante Incentive Compatible Core in Exchange Economies with and without Indivisibilities, March 2006

1687 Assar Lindbeck, Mårten Palme and Mats Persson, Job Security and Work Absence: Evidence from a Natural Experiment, March 2006

1688 Sebastian Buhai and Coen Teulings, Tenure Profiles and Efficient Separation in a Stochastic Productivity Model, March 2006

1689 Gebhard Kirchgaessner and Silika Prohl, Sustainability of Swiss Fiscal Policy, March 2006

1690 A. Lans Bovenberg and Peter Birch Sørensen, Optimal Taxation and Social Insurance in a Lifetime Perspective, March 2006

1691 Moritz Schularick and Thomas M. Steger, Does Financial Integration Spur Economic Growth? New Evidence from the First Era of Financial Globalization, March 2006 